\title{
Vemodig og engasjerende om lengsel, kjærlighet og katastrofal inkompetanse
}

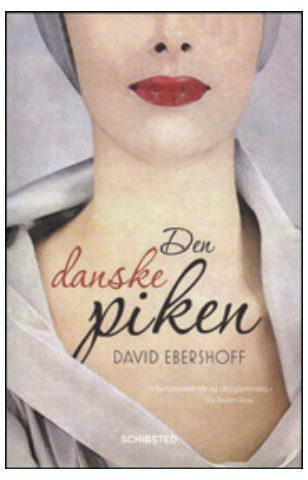

Boken er oversatt fra engelsk av Christina Mediaas. Oversettelsen er så langt denne anmelderen kan vurdere, god, om enn ikke helt fri for litt tunge formuleringer. Fordi boken fremstår som en roman, er det lett å følge historien og lett å bli engasjert av den.

Hovedpersonene Einar Wegener - senere Lilli Elbe - og Wegeners kone Gerda var uvanlige i første halvdel av forrige århundre og ville vært uvanlige i dag. Einar fordi han/hun først kommer til erkjennelse av sin kvinnelighet i 30-årsalderen, en kvinnelighet som inspirerer en lengsel etter mer kvinnelighet, og fordi det er forhold ved kroppen hans/hennes som ikke passer inn i kjente kroppslige sjeldenheter. Wegener synes å menstruere, i alle fall kommer det regelmessig blod via Wegeners penis. Gerda blir uvanlig fordi hun i så stor utstrekning synes både å romme Einars kjønnsovergang og å forstå hvem som er, og hvem som ikke er, gode hjelpere i denne prosessen.

Både Einar og Gerda er kunstmalere, hun i utgangspunktet langt mindre kjent enn ham, et forhold som endrer seg i bokens løp. Det er det mye annet som gjør også.

Gerda oppdaget Einar da hun studerte kunst i Danmark. Einar var sky og tilbakeholden, slik at den unge og pågående amerikanske damen på ingen måte fikk snøret i bunnen. Hun dro tilbake til USA, giftet seg med en utmerket mann og ble hos ham til han døde. Da dro Gerda tilbake til København, fast bestemt på å finne tilbake til Einar. Det gjør hun, de gifter seg, og begge maler bilder: han av landskaper, hun av personer. I tillegg tegner hun erotiske illustrasjoner til forskjellige slags tidsskrifter.

Gerda maler et helkropps portrett av operasangerinnen Anna og kommer en ettermiddag i beit for et par damebein å male etter. Gerda kaller på mannen, Einar, som ikke uten motvilje stiller opp i kjole, sko og silkestrømper.

Motviljen til tross, Einar liker det, og Gerda elsker det. Drevet av hver sin lyst blir Einar oftere og oftere iført kvinneklær, sminket, pyntet og plassert i atskillige posisjoner der Gerda kan male «henne».

Lysten drar Einar forbi Gerdas staffeli. Den danske piken vil ut. «Hun» vil på ball, hun vil danse, hun vil jobbe og få seg en kjæreste. Alt dette får hun da også mens Gerda maler henne, og bildene Gerda maler av denne mystiske kvinnen, vil alle ha. Gerdas berømmelse vokser.

De lever sitt uvanlige liv i København og senere i Paris, og de står hverandre svært nær, samtidig som denne nye danske piken bidrar til å endre karakteren av parforholdet deres. Det blir mindre sex, det blir mer kvinnefellesskap og stadig mindre plass til Einar.

Gerda synes å ane hvor det bærer hen. Einar vet etter hvert at valget står mellom ham og den danske piken. Wegener er i en eksistensiell krise i valget mellom manndom og kvinnelighet. Han velger kvinneligheten.

Likevel må han innom «ekspertisen». Wegeners kropp gjøres til gjenstand for røntgenbehandling. Store doser mot underlivet skal «kurere alt». Vi kjenner sporene av denne behandlingen på Wegeners kropp i resten av boken. Psykiater blir også tilkalt for å avhjelpe Wegeners «problem». Psykiateren snakker varmt om lobotomi som en løsning på problemet. Den gang som nå er ikke psykiatrien rett sted å gå for dem med denne typen utfordring.

Vi står overfor et etisk dilemma som ennå ikke er avklart: Hvem bestemmer over andres selvforståelse, og hvilke samfunnsmessige og kroppslige krav skal legges til grunn for hva leger kan og ikke kan tillate seg i vitenskapens navn?

Det blir bedre da den danske piken treffer en kirurg, som ikke er helt ukjent med, skal vi kalle det, «transfenomener». Han er på parti med hennes lengsel og tror seg på parti med menneskekroppens muligheter. Han stiller seg til kirurgisk disposisjon, og bit for bit blir Wegeners mannekropp justert i kvinnelig retning.

Det går ganske greit fra begynnelsen, men Wegener som etter hvert har tatt navnet Lilli Elbe, lengter etter og drømmer om å bli mer kvinne, enda mer kvinne, så mye kvinne at hun skal kunne bære frem sitt eget og mannens barn. Verken Lilli eller kirurgen forstår at hun aldri kan bli fullstendig. Den gang, som nå, kan hun bare bli helt seg selv, og det selvet kom til verden i en mannekropp.

Det ligger en avgrunn i Lillis lengsel og en like stor avgrunn i kirurgens klokketro på egen fortreffelighet. Gerda Wegener går av på nest siste stasjon, og hun lar livet gå videre i et annet parforhold. Lilli og kirurgen går sammen mot avgrunnen, bare kirurgen vender tilbake.

Esben Esther Pirelli Benestad

Helse og idrett

Universitetet i Agder

Kristiansand 